\author{
Małgorzata Sokalska \\ Uniwersytet Jagielloński \\ malgorzata.sokalska@uj.edu.pl
}

\title{
Dźwiękiem i słowem o poezjach Mickiewicza. Wokół lektury książki Stanisław Moniuszko i inni kompozytorzy wobec poezji Adama Mickiewicza
}

\author{
About Poetry of Adam Mickiewicz in Terms of Tones and Words. Around \\ the reading of the book Stanistaw Moniuszko $i$ inni kompozytorzy wobec poezji \\ Adama Mickiewicza
}

\begin{abstract}
The map of the Polish interdisciplinary music-literary research has been enriched during the last years with significant theoretical and analytic-interpretative publications. Researchers from various disciplines attempt to specify the types of relations that can interconnect the literary text and music - focusing not only on the problem of interference between two systems using different signs but also more and more emphasizing the cultural meaning of the phenomena of this kind. The article comments on the horizons of the Polish research devoted to these issues. It situates in this context the book by Małgorzata Sułek Stanisław Moniuszko and other composers and poetry by Adam Mickiewicz, published in 2016. This study offers also a methodological proposal, organizing the reflections on certain aspects of comparative studies (in the introductory treatise). In the second part it collects the rich analytical material. The musical arrangements of poetry by Mickiewicz, created during 19th to 21 th centuries, allow to systematically know a non-obvious aspect of the reception of the heritage of the most famous Polish romantic, various ways of approaching his works and interpreting them - with the use of music.
\end{abstract}

Keywords: romantic song, ballad, Adam Mickiewicz, Stanisław Moniuszko, musicalization of poetry

Streszczenie: Mapa polskich badań interdyscyplinarnych literacko-muzycznych wzbogaciła się w ostatnich latach o ważne pozycje teoretyczne oraz analityczno-interpretacyjne. Badacze reprezentujący różne dyscypliny próbują wciąż dookreślić typy relacji, jakie mogą łączyć tekst literacki z muzyką - skupiając się nie tylko na problemie interferencji dwóch systemów operujących odmiennymi znakami, ale także coraz mocniej akcentując kulturowe znaczenie tego rodzaju zjawisk. Artykuł komentuje horyzonty polskich badań poświęconych tej problematyce oraz lokuje na tym tle wydaną w 2016 roku książkę Małgorzaty Sułek Stanistaw Moniuszko i inni kompozytorzy wobec poezji Adama Mickiewicza. Studium to stanowi zara- 
zem propozycję metodologiczną, porządkującą refleksję na temat pewnych aspektów badań porównawczych (w rozprawie wstępnej), w drugiej zaś części gromadzi bogaty materiał analityczny. Powstałe od XIX wieku do teraz muzyczne opracowania poezji Mickiewicza pozwalają się zapoznać w usystematyzowany sposób z nieoczywistym aspektem recepcji spuścizny najsłynniejszego polskiego romantyka, różnymi sposobami traktowania jego dzieł i interpretowania ich - za pomocą tworzywa muzycznego.

Słowa kluczowe: pieśń romantyczna, ballada, Adam Mickiewicz, Stanisław Moniuszko, umuzycznienie poezji

Nie będzie przesadą stwierdzenie, że badania literacko-muzyczne i muzyczno-literackie na trwałe przeorientowały współczesny sposób myślenia o literaturoznawstwie (a po części także muzykologię). Od czasu gdy Andrzej Hejmej stwierdzał, że „[w]spółczesne badania literackie oraz teoretycznoliterackie (...) stosunkowo rzadko sygnalizują zjawisko muzycznych filiacji dzieła literackiego" ${ }^{1}$, zmieniło się tak wiele, że obecnie można mówić raczej o trudnościach w uchwyceniu tego bogactwa i usystematyzowaniu rozmaitych propozycji płynących ze strony współczesnych badaczy niż o niedostatku tego rodzaju rozważań. Ten bujny rozkwit dotyczy przede wszystkim zjawiska, któremu sam Hejmej nadał wyraziste ramy i które stało się obiektem jego wzmożonego zainteresowania również w kolejnych fundamentalnych dla dziedziny pracach ${ }^{2}$. Sporo szczęścia miały też w ostatnich latach badania poświęcone konkretnym gatunkom synkretycznym, takim jak opera ${ }^{3}$, w których konsekwentnie uzupełniały się perspektywy zbieżne z trajektorią teorii Hejmeja skupione na literackich śladach opery jako gatunku muzycznego, a także reprezentujące kierunek komplementarny - ukazujący operę jako obszar działań rozmaitych dziedzin kultury oraz rozliczne interferencje zachodzące między nią a na przykład zjawiskami literackimi ${ }^{4}$.

${ }^{1}$ A. Hejmej, Muzyczność dzieta literackiego, Wrocław 2001, s. 5.

${ }^{2}$ Wymienić tu warto zarówno pełniący funkcję popularyzującą zbiór Muzyka w literaturze. Antologia polskich studiów powojennych, red. A. Hejmej, Kraków 2002, jak i kolejną kompleksową propozycję badań tej dziedziny płynącą od tego samego autora - A. Hejmej, Muzyka w literaturze. Perspektywy komparatystyki interdyscyplinarnej, Kraków 2008.

${ }^{3}$ Dzięki serii monografii zbiorowych publikowanych przez ośrodek skupiony wokół Centrum Badań nad Teatrem Muzycznym Uniwersytetu im. Adama Mickiewicza w Poznaniu. Zob. Opera wobec historii, red. R.D. Golianek, P. Urbański, Toruń 2012; „Natchnienia poety i muzyka żenić się z soba powinny”. Studia i szkice o libretcie, red. E. Nowicka, A. Borkowska-Rychlewska, Poznań 2013; Operowy kontrapunkt. Libretto w Europie Środkowej $i$ Wschodniej, red. B. Judkowiak, K. Lisiecka, Poznań 2014; Libretto i przektad, red. E. Nowicka, A. Borkowska-Rychlewska, Poznań 2015; Miraże identyfikacji. Libretto w operze XX i XXI wieku, red. A. Borkowska-Rychlewska, E. Nowicka, Poznań 2015; Teatr muzyczny Verdiego $i$ Wagnera. Konteksty literatury $i$ kultury, red. R.D. Golianek, H. Winiszewska, Poznań 2015.

${ }^{4}$ Ten dwoisty kierunek reprezentują takie tomy, jak Od literatury do opery $i$ z powrotem. Studia nad estetyka teatru operowego, red. R.D. Golianek, P. Urbański, Toruń 2010, oraz Opera w kulturze, red. M. Sokalska, Kraków 2016. 
Obserwacja rozwoju badań pogranicznych i wynikająca stąd niewątpliwa satysfakcja ze strony każdego zainteresowanego tą dziedziną nie powinny przesłonić faktu, że nie wszystkie zjawiska muzyczno-literackie obdarzano ostatnio równym zainteresowaniem. I choć per saldo w tradycji polskiej również pieśń bywała obiektem wzmożonego naukowego namysłu, wydaje się jednak, że ten akurat gatunek oraz problematykę teoretyczną i interpretacyjną z niego płynącą ostatnio nieco zaniedbano ${ }^{5}$. Książka, która stanie się przewodnikiem poniższych rozważań o kulturowej roli pieśni, o jej znaczeniu, widzianym zarówno ze stanowisk muzykologicznych, jak i literaturoznawczych, ukazała się niemal jednocześnie z inną pozycją, poświęconą pieśniom Franza Liszta $^{6}$. W oczekiwaniu na renesans interdyscyplinarnego namysłu nad pieśnią czy również piosenką ${ }^{7}$ - analogiczny do tego, który spotkał refleksję nad muzyką w literaturze oraz nad operą - wypada głębiej pochylić się nad niedawno wydanymi pozycjami, z których zwłaszcza ta poświęcona poezji Adama Mickiewicza w pieśni zainteresować może nie tylko poszerzających horyzonty swojej dziedziny literaturoznawców, ale także wielbicieli powszechnie znanych utworów poetyckich, należących do kanonu literatury narodowej.

Biorąc do ręki książkę Małgorzaty Sułek ${ }^{8}$, czytelnik może się poczuć nieco onieśmielony obszernością tego tomu, liczącego ponad siedemset stron, $\mathrm{w}$ sporej swojej części wypełnionego materiałem o charakterze analitycznym (s. 45-650), inkrustowanym przykładami nutowymi. Trzeba wszak zdać sobie sprawę z tego, że całościowa lektura książki - przez odbiorcę, którym może (powinien nawet) być literaturoznawca, muzykolog, komparatysta, badacz lub po prostu miłośnik kultury literacko-muzycznej ostatnich dwóch stuleci - nie jest nieodzowna, przynajmniej zaś nie jako lektura ciągła i jednorazowa. Tom ów jednak, co trzeba podkreślić w nawiązaniu do powyższych uwag na temat rozwoju badań komparatystycznych o profilu interdyscyplinarnym, właśnie ze względu na swój monograficzny charakter wypełnia lukę, dającą się zauważyć w dotychczasowych eksploracjach dziedziny.

5 Wrażenie osłabienia tego pola badawczego płynie przede wszystkim z faktu, że ostatnią spójną i szeroko zakrojoną inicjatywą w tym zakresie była seria „Muzyka i Liryka” wydawana przez krakowską Akademię Muzyczną w latach 1989-2002 (łącznie 10 tomów).

${ }^{6}$ M. Gamrat, Między stowem a dźwiękiem. Pieśni na gtos i fortepian Franza Liszta, Warszawa 2016.

7 Ten wątek rozważań, prowadzący ku twórczości popularnej, należy również lokować w obrębie pola badawczego wyznaczonego przez zainteresowanie gatunkami synkretycznymi. Pomimo pewnego ożywienia tego rodzaju refleksji naukowej w Polsce, datującego się od czasów rozprawy Anny Barańczak, Stowo w piosence. Poetyka polskiej piosenki estradowej, Wrocław 1983, bogactwo piosenki nie doczekało się systematycznych opracowań i kompleksowych propozycji metodologicznych. Niewątpliwie jednak na uwagę zasługują propozycje Marka Traczyka, Poezja w piosence. Od Tuwima do Świetlickiego, Poznań 2009, czy Joanny Maleszyńskiej, Apologia piosenki. Studia z historii gatunku, Poznań 2013.

${ }^{8}$ M. Sułek, Stanistaw Moniuszko i inni kompozytorzy wobec poezji Adama Mickiewicza. Studium komparatystyczne, Kraków 2016. 
Zarówno temat stosunku wieszczów do sztuki muzycznej, jak i kwestia relacji odwrotnej, a zatem świadectwa muzycznej recepcji dzieł literackich, stawały się już obiektem głębszego zainteresowania w polskich badaniach?. Jeśli jednak nawet podejmowano próby dookreślenia sposobów funkcjonowania konkretnego gatunku (pieśń/ballada, szerzej rozumiana liryka wokalna) lub tworzono katalogi tego typu twórczości, brakowało przecież - do czasu ukazania się omawianej książki - ujęcia tak kompletnego. Należy przez to rozumieć nie tylko wyjście poza najlepiej rozpoznany, a mimo to wciąż jeszcze ostatecznie nieopracowany repertuar Moniuszkowski, co skromnie zaznaczone zostało w tytule tomu (,i inni kompozytorzy”), ale także zastosowanie analityczno-interpretacyjnej metody badań. W omawianej książce czytelnik znajdzie bowiem nie tylko informacje o istnieniu jakiegoś utworu adaptującego do śpiewu tekst Mickiewicza, ale przede wszystkim pogłębioną propozycję odczytania tego dzieła - interpretację podstawy literackiej i krytyczny rozbiór licznych opracowań muzycznych. Jeśli zatem twierdzę, że książkę Stanistaw Moniuszko $i$ inni kompozytorzy wobec poezji Adama Mickiewicza czytać można wybiórczo - sięgając po analizy konkretnego wiersza lub ballady albo korzystając z niezwykle bogatego opracowania bibliograficznego, licznych aneksów czy też ograniczając się do wstępu do książi jako osobnej i poniekąd samodzielnej rozprawy - to nie jest to zarzut, ale raczej potwierdzenie bardzo szerokiej funkcjonalności tomu wydanego w serii „Acta Musicologica Universitatis Cracoviensis”.

Autorka publikacji ma w swoim dorobku prace poświęcone zbliżonej tematyce, w tym pieśniom Witolda Lutosławskiego ${ }^{10}$, lokujące pieśni w perspektywie badań nad fenomenami socjokulturowymi ${ }^{11}$, ale również przybliżające twórczość kompozytorów związanych z opracowaniami tekstów Mickiewicza, w tym Stanisława Moniuszki ${ }^{12}$ czy Franciszka Godebskiego ${ }^{13}$. Omawiana książka stanowi zatem kontynuację i zarazem ukoronowanie tych badań.

Punktem wyjścia rozważań Sułek staje się zjawisko romantycznej korespondencji sztuk. Co prawda, badaczka we Wstępie odżegnuje się od drobiazgowego rekonstruowania zakresu znaczeniowego tego pojęcia (jak i innych, na tle których lokuje badane przez siebie pieśni), nie mnoży też przykładów

${ }^{9}$ Na szczególną uwagę zasługuje tu doskonała książka A. Seweryn, Poezja „nutami niesiona”. O muzycznej recepcji twórczości Juliusza Stowackiego, Warszawa 2008, w której w sposób uporządkowany i kompletny zaprezentowano bogactwo muzycznych opracowań twórczości jednego z luminarzy polskiego romantyzmu.

${ }_{10}$ M. Sułek, Pieśni masowe Witolda Lutostawskiego w kontekśsie doktryny realizmu socjalistycznego, Kraków 2010.

${ }^{11}$ Taż, Pieśni masowe o Nowej Hucie, „Zeszyty Naukowe Towarzystwa Doktorantów UJ” 2010, z. 1 .

${ }_{12}$ Taż, „Widma” Moniuszki wobec „Dziadów” Mickiewicza [w:] Teatr muzyczny Stanistawa Moniuszki, red. M. Dziadek, E. Nowicka, Poznań 2014.

13 Taż, Mickiewiczowskie „Pieśni mitosne” Franciszka Godebskiego [w:] Almanach muzykologii krakowskiej: 1911-2011, red. M. Woźna-Stankiewicz, Z. Dobrzańska-Fabiańska, A. Sitarz, Kraków 2016. 
jego konkretyzacji w kulturze romantycznej, niemniej jednak sygnalizuje najistotniejsze pozycje bibliograficzne poświęcone tej tematyce i umiejętnie łączy ją z aspektem teoretycznym, a więc współczesnym spojrzeniem na relacje literatury i muzyki jako przestrzeń intermedialności. Refleksja teoretyczna nad tak zwaną muzycznością literatury powróci jeszcze mniej więcej w połowie wstępu, co skutkuje przywołaniem w przypisach kolejnych pozycji bibliograficznych (s. 20-21), a w rezultacie uświadamia czytelnikowi złożony charakter prezentowanej problematyki i jej wcale nie tak skromną tradycję badawczą. Zdaniem autorki muzyczność poezji jest jedną z cech umożliwiających wyjaśnienie powodów wyboru konkretnego tekstu jako podstawy dzieła wokalnego. Dalsze uwagi nieco tę konstatację osłabiają, badaczka słusznie bowiem zauważa, że nie zawsze uznawane za skądinąd muzyczne wiersze cieszą się popularnością wśród kompozytorów. Ostatecznie trudno oprzeć się wrażeniu, że głównymi przyczynami, dla których kompozytorzy sięgają po omówione w książce wiersze akurat Mickiewicza, są wspomniane we wstępie (s. 19) powody natury historyczno-obyczajowej, związane z silną dominantą patriotyczną odbioru dzieł tego poety. Być może zresztą należałoby baczniejszą uwagę zwrócić na inny aspekt tematu, a mianowicie kwestię kultury pieśniowej dziewiętnastego stulecia i skutków, jakie dla recepcji danego poety ma umuzycznienie jego poezji?

Zagadnienie to nie zostało całkowicie pominięte przez autorkę, która zwróciła uwagę na istniejące badania nad muzyczną recepcją twórców polskich od przykładów staropolskich, w tym Jana Kochanowskiego, Mikołaja Reja, czy Wespazjana Kochowskiego, poprzez najszerzej reprezentowane grono literatów romantycznych aż po twórców dwudziestowiecznych. Autorka nie rozróżniła, co prawda, prac związanych z różnymi typami relacji literacko-muzycznych, a więc aspektami muzyki w twórczości i twórczości w muzyce, ale słusznie zauważyła mniejszą frekwencję badań podjętych „z uwagi na dzieło muzyczne wykorzystujące tekst literacki" (s. 19), dodając także, że ich ukierunkowanie zwykle ma charakter analityczno-porównawczy, jako że skupiają się na zestawieniu różnych kompozycji muzycznych operujących tym samym tekstem literackim.

W tym miejscu można byłoby spodziewać się wyraźnej deklaracji, że również niniejsza książka przyjmuje tę właśnie optykę metodologiczną, co podkreśliłoby włączenie się w pewien tradycyjnie uprawiany w polskim literaturoznawstwie model. Byłoby to o tyle ważne, że w kolejnym akapicie rozprawy ujawniony został ambiwalentny stosunek autorki do wybranego profilu badawczego. Gromadzenie przykładów muzycznej recepcji tego samego dzieła literackiego - multiplikowanych przez kolejnych kompozytorów pieśni opartych na tej samej podstawie tekstowej - stanowi, rzecz jasna, „bezsporne świadectwo nieustannego, niepowstrzymywanego przez zmieniające się na przestrzeni dziejów tendencje, nurty i kierunki, wzajemnego (...) oddziaływania na siebie literatury i muzyki” (s. 19). Prowokujące do porównań i zestawień bogactwo materiału jest jednak zarazem przeszkodą w badaniach, budząc uzasadnione wątpliwości co do kompletnego charakteru zgromadzonej podstawy 
badawczej, na której badacz opiera swoje rozpoznania. Brak ograniczenia czasowego (na przykład wyłącznie do recepcji dziewiętnastowiecznej) to zarazem duża zaleta omawianej monografii, która przybliża czytelnikowi także zupełnie nieznane, współczesne kompozycje, a także cecha ostatecznie przypieczętowująca swoiście aktualny, zatem intencjonalnie niepełny obraz zagadnienia, utrwalający jego bieżący obraz - z pełną świadomością możliwego dalszego dynamicznego rozwoju.

Warto byłoby w tym miejscu wspomnieć o jeszcze jednym wątku, który Małgorzata Sułek w swoich ustaleniach pominęła, nie wyjaśniając powodów odrzucenia innej koncepcji kompozycyjnej czy też nie uzasadniając szerzej celowości wybranego przez siebie porządku wywodu. Myślę tu o zastosowaniu innego przekroju: skupieniu na opracowaniach poezji Mickiewicza w twórczości konkretnych kompozytorów. Szeregując analizy i interpretacje wedle klucza tematycznego, zatem poddając omówieniu poszczególne wiersze i uporządkowane chronologicznie ich opracowania pieśniowe, badaczka straciła możliwość interpretacji serii Mickiewiczowskich umuzycznień w obrębie twórczości różnych kompozytorów, przeprowadzenia dowodu na istnienie spójnych (lub owej spójności pozbawionych) sposobów czytania poezji, personalnych predylekcji do poszukiwania w dorobku autora Dziadów konkretnych walorów. Rezygnacja z uporządkowania wedle kompozytorów zmarginalizowała także wagę refleksji na temat kształtowanego przez nich obrazu Mickiewicza muzycznego. Patrząc wszak z tej perspektywy, można byłoby zbadać kilka interesujących kwestii, na przykład istnienia Moniuszkowskiego idiomu pieśni Mickiewiczowskiej popularyzowanego wśród użytkowników Śpiewników domowych, zakresu dialogu Władysława Żeleńskiego z tradycją dzieła Moniuszki, form modernizowania języka pieśni Mickiewiczowskiej przez Ignacego Jana Paderewskiego czy też rozpoznawalności polskiego poety w kręgu kompozytorów rosyjskich. Interesujące wydają się w takim ujęciu nie tylko środki kompozytorskiej techniki, jakich używają dani twórcy w odniesieniu do repertuaru pieśni Mickiewiczowskiej, ale także - czy nawet przede wszystkim - dokonywane przez nich wybory konkretnych wierszy, które mogłyby dać asumpt do wysuwania dalszych wniosków interpretacyjnych.

Z uwagi na znikomą popularność niektórych omawianych w książce kompozytorów dla czytelnika tomu pewnym utrudnieniem może być to, że w zaproponowanym uporządkowaniu uwagi ogólne - na temat funkcjonowania pieśni do słów Mickiewicza w całokształcie działalności artystycznej danego twórcy albo chociaż wymieniające tytuły tomów jego pieśni, okoliczności ich publikacji - podane zostaja, co oczywiste, przy okazji pierwszej analizowanej jego pieśni. Oznacza to wszakże, że sięgając w lekturze wyłącznie po jeden rozdział książki, w którym ów mniej znany kompozytor pojawi się po raz kolejny, prawdopodobnie nie dotrzemy do kilku interesujących informacji o owej postaci i jego dziele, jakie przytoczone zostały przez autorkę wcześniej. 
Pomimo powyższych dywagacji na temat odmiennego sposobu skomponowania książki trzeba podkreślić, że dokonany przez Sułek wybór koncepcji badań i kompozycji całej monografii uznać należy za trafniejszy i lepiej dopasowany do celów, jakie badaczka postawiła przed swoim projektem, niż gdyby zastosowano inną strukturę prezentacji tego materiału. Postulować by jedynie należało głębsze wtajemniczenie czytelnika w owe odmienne możliwości uporządkowania tematu i inne aspekty badań, jakim mógłby posłużyć wybrany zakres materiałowy. To istotne z punktu widzenia kontynuacji badań, których mamy prawo oczekiwać - czy ze strony autorki, czy jej następców, którzy zechcą podążyć wybranymi tropami tej interesującej monografii. Niewątpliwie bowiem, sięgając po książkę Sułek, badacz związków literatury i muzyki, muzyki wokalnej zyskuje nieograniczone niemal możliwości dekomponowania ścisłej i konsekwentnie uporządkowanej jej zawartości oraz aranżowania dla własnych potrzeb dowolnych układów, w tym choćby tematycznych (na przykład interpretacje różnych pieśni Mickiewicza dobranych wedle klucza tematologicznego), personalnych (wspomniana już wyżej kwestia recepcji dzieł autora Pana Tadeusza w twórczości wybranych kompozytorów), chronologicznych (odbiór pieśni Mickiewicza w pierwszych dekadach XX wieku, współczesne odczytania pieśniowe jego wierszy i inne), a nawet wydzielanie grup pieśni z uwagi na ich obsadę (pieśni solowe, zespołowe, chóralne). Co warte podkreślenia, autorka wymieniła również te kompozycje wokalne do słów Mickiewicza, które z różnych przyczyn (zwykle ze względu na inną niż pieśń i ballada przynależność gatunkowa) nie zostały omówione w książce (s. 38-41) lub też których istnienie jest poświadczone, ale nie udało się odnaleźć ich zapisu.

Zaproponowany układ kompozycyjny książki, jego przejrzystość, łatwość nawigacji po ogromnym przecież zasobie Mickiewiczowskiego śpiewnika to niekwestionowane zalety tej publikacji, w której - jak anonsuje Sułek porównano dwa typy interpretacji: literaturoznawczo-filologicznej i muzykologicznej (s. 22), przy tym ta druga świadomie została znacznie ograniczona do uwag sfunkcjonalizowanych z punktu widzenia interpretacji literackiej i kulturowej. Zagadnieniu owego zawieszenia metodologicznego komparatystycznej lektury pieśni między perspektywą literaturoznawczą i muzykologiczną autorka poświęca sporo uwagi w dalszych partiach wstępu, ponieważ, jak stwierdza, wybór metody badań porównawczych:

umożliwia objęcie analizą porównawczą kompozycji wybitnych i miernych, różniących się stylistyką i cechami muzycznymi, napisanych w różnych epokach, z których każda rządziła się innymi zasadami kształtowania materiału muzycznego, odmiennym rodzajem ekspresji, a także prezentowanym w pracach teoretycznych i praktyce kompozytorskiej sposobem podejścia do relacji między słowem i dźwiękiem (s. 25).

Jest to również decyzja metodologiczna, która zachęca do zajmowania wobec analizowanych pieśni i ballad stanowiska wartościującego, oceniania 
między innymi oryginalności podejścia kompozytorów do tekstów Mickiewicza oraz zbieżności interpretacji muzycznej i kształtowanej przez lekturę filologiczno-literaturoznawczą. Zapowiedziana we wstępie postawa autorki wobec omawianego materiału znajduje pełne potwierdzenie w zasadniczej części książki; poszczególne analizy i interpretacje gęsto okraszone są stwierdzeniami o charakterze oceniającym. Sułek nie waha się różnicować, waloryzować kompozycji, które jej zdaniem lepiej wywiązują się ze swoich obowiązków względem opracowywanego tekstu, stoją na wyższym poziomie artystycznym, oraz ganić tych, które oparto na chybionych założeniach lub mają charakter wtórny i nie wnoszą do interpretacji tekstu nic interesującego. Prowadzi to niekiedy do weryfikacji sądów stawianych przez poprzedników odmawiających czasem większych wartości niektórym pieśniom, podczas gdy - czytane w zaproponowanej przez Sułek perspektywie - odsłaniają dość nieoczekiwanie pomijane uprzednio zalety.

Wyeksponowanie zarówno tytułem, jak i zawartością samego tomu stanowisko Moniuszki jako interpretatora Mickiewicza zostało szeroko uzasadnione i zaowocowało we wstępie do tomu kolejnym rozwiniętym passusem bibliograficznym (s. 28-29) oraz wyliczeniem głównych aspektów tego tematu (s. 34-35). Tu także poszerzono sygnalizowane już uprzednio kwestie związane z muzycznymi uwikłaniami twórczości i recepcji samego Mickiewicza (s. 31-35).

Trzon książki stanowią rozdziały analityczno-interpretacyjne, podzielone wedle klucza gatunkowego (I: pieśni, II: ballady). W tytułach poszczególnych fragmentów zwracają uwagę nieco sztampowe i nie zawsze adekwatne do ich zawartości formuły (jak np. „Do D.D. - namiętność przy akompaniamencie ptasich treli” lub „Czaty - brzmienie i dramaturgia furii” czy „Powrót taty - muzyczna reprezentacja modlitwy i zbójeckiej napaści”). Zapewne autorka chciała $\mathrm{w}$ ten sposób zasygnalizować kierunek interpretacji, podsumować jakoś dany rozdział, a także zróżnicować poszczególne partie, które poza tym charakteryzuje radykalne zdyscyplinowanie kompozycyjne i lustrzany porządek kolejnych ogniw wywodu. Badaczka skupia się najpierw na samym tekście, okolicznościach jego powstania i wariantach oraz kreśli zarys jego interpretacji, w czym towarzyszą jej wybrane prace literaturoznawcze (ich wybór nie budzi wątpliwości; są to zwykle najcelniejsze, choć i zarazem najbardziej tradycyjne, analizy i interpretacje autorstwa wybitnych badaczy, między innymi Wacława Borowego, Jacka Brzozowskiego, Juliusza Kleinera, Zofii Szmydtowej, Józefa Tretiaka, Aliny Witkowskiej czy zwłaszcza Czesława Zgorzelskiego). Po tej części następują zwięzłe informacje o popularności danego tekstu w opracowaniach muzycznych, a wreszcie interpretacje kolejnych pieśni. Oprócz krótkiego zarysu okoliczności powstania poszczególnych umuzycznień, które to informacje w wybranych punktach obudowane są stosownym aparatem krytycznym (o ile takowy w ogóle istnieje; wiele analizowanych pieśni nie ma jednak żadnej tradycji badawczej - i tu uwagi autorki nabierają charakteru całkowicie pionierskiego), Sułek podkreśla ważną dla 
koncepcji książki popularność dzieł Moniuszki. Rozpowszechnienie jego pieśni jest ważnym aspektem ze względu na wtórność niektórych późniejszych opracowań (zwrócono uwagę na ten fakt chociażby w wypadku Snu, s. 5355). Każdy z rozdziałów wieńczy wreszcie krótkie porównawcze podsumowanie, w którym autorka poszukuje podobieństw i różnic, stawia tezy dotyczące głównej linii lektury muzycznej, jakiej kompozytorzy poddali dany tekst Mickiewicza. Tego rodzaju wniosków - na bieżąco dokonujących porównań i zestawień pieśni - jest w książce całkiem sporo, co dodatkowo uwypukla komparatystyczny zamysł opracowania, ale też, zgodnie z podkreślonym wyżej założeniem nieuchylania się od sądów oceniających, otwiera przed autorką możliwość wypowiedzi na temat walorów poszczególnych kompozycji, uwypuklających się zwłaszcza wówczas, gdy można je zobaczyć przez pryzmat innych opracowań tego samego tekstu.

Uwagi na temat kolejnych umuzycznień pieśni i ballad bez wyjątku sprofilowane zostały w ten sposób, by wyeksponować kwestię relacji warstwy muzycznej ze słowami. Autorka konsekwentnie analizuje tekst muzyczny $\mathrm{w}$ jego dialogu $\mathrm{z}$ tekstem literackim - nie jako dzieło wyłącznie muzyczne, ale jako objaw kompozytorskiego namysłu nad opracowywanym wierszem, syntezę doświadczeń artystycznych muzyka i impulsów płynących z liryków i ballad Mickiewicza. Dzięki temu postępowaniu w książce rysuje się bardzo szeroka panorama zjawisk kultury, przede wszystkim XIX wieku. Omawiając na przykład Sen Maurycego Karasowskiego (s. 60-62), badaczka zwróciła uwagę na wykorzystanie w nim idiomu nokturnu chopinowskiego (co powiązane zostało z naukowymi zainteresowaniami kompozytora, który był jednym z najważniejszych badaczy muzyki i biografii Fryderyka Chopina w epoce). W szczególnie interesującej interpretacji Niepewności Moniuszki (s. 82-86) Sułek formułuje tezę o świadomym potraktowaniu przez kompozytora tekstu Mickiewicza à rebours - wskazane środki muzyczne, w tym ironicznie zastosowane chwyty retoryki barokowej, unieważniają wahanie Mickiewiczowskiego podmiotu, ujednoznaczniając emocjonalny wybór jednego tylko z uczuć, których istnienie dopuszczało ja liryczne w wierszu.

Rozważania poświęcone wierszowi Do D.D. wzbogaciło imponujące zestawienie kompozycji inspirowanych tym lirykiem (s. 112-113), dowodzące, że rzeczywiście należy mu się miano najpopularniejszego spośród tekstów Mickiewicza. $Z$ uwagi na mnogość opracowań muzycznych powstałych w rosyjskim kręgu kulturowym rozdział ten szczególnie interesująco wprowadza czytelnika w meandry muzycznej recepcji wierszy Mickiewicza na Wschodzie. W warstwie komentarza porównawczo-oceniającego badaczka stawia ciekawe tezy, wyrażając między innymi przekonanie, że Michaił Glinka i Fryderyk Chopin podobnie skupili się na oddaniu erotyzmu liryku, choć: 
obaj twórcy pojmowali go odmiennie. Chopin konsekwentnie budował muzyczną narrację, obrazując narastanie pożądania; „ja” liryczne kompozycji Glinki jest z kolei rozdarte pomiędzy dwoma sprzecznymi uczuciami: delikatnością a gwałtownością. W pieśni Chopina podmiot liryczny jest nie tylko skoncentrowany na własnych pragnieniach, ale także w pełni ich świadomy; w dziele Glinki odznacza się niezdecydowaniem, przeradzającym się momentami w śmiałość, która jednak prędko ustępuje brakowi pewności siebie (s. 129).

Zacytowany fragment wywodu ukazuje wyraźnie, że w badaniach Sułek pieśni rysują się jako głęboko znaczące, zakodowane w materiale muzycznym interpretacje tekstów literackich. Badaczka stara się przede wszystkim odpowiedzieć na pytanie: jak kompozytor rozumie opracowywany tekst?

Omówienie pieśni opartych na Mickiewiczowskiej parafrazie Kennst du das Land Johanna Wolfganga Goethego - Do $H^{* * *}$. Wezwanie do Neapoluwpisuje problematykę opracowań muzycznych wierszy polskiego poety w szersze europejskie konteksty, a zarazem przywołuje liczne refleksje nad romantyczną parafrazą i znaczeniami, jakie twórca nadał własnemu tekstowi, rozpiętemu wszak na szkielecie formy i sensów zapożyczonych z oryginału. Kwestia szerszych filiacji tego tekstu, zatem rozlicznych zachodnich umuzycznień wiersza Goethego, potraktowana została jedynie w przypisowy sposób, co jest jednak w pełni uzasadnione ogromnym bogactwem opracowań samego wiersza Mickiewicza. Kluczowe miejsce zajmuje w tej partii książki pieśń Moniuszki - jest to bowiem kompozycja, która w determinujący sposób wpłynęła „na wszystkie dziewiętnastowieczne muzyczne opracowania Do $H^{* * * *}$ (s. 258). Przykładem tym dowodzi badaczka słuszności fundamentalnego założenia książki, jakim jest wyeksponowanie twórczości Moniuszki, potraktowanie jej jako rodzaju klucza do interpretacji dokonań innych polskich kompozytorów. Rozpisany na głosy Józefa Nowakowskiego, Adama Grossa, Wilhelma Czerwińskiego, Stanisława Niewiadomskiego, Apolinarego Szeluty, Andrzeja Cierniewskiego i Lecha Makowieckiego kompozytorski dialog z Wezwaniem do Neapolu dowodzi, jak silny wpływ miał Moniuszko na ukształtowanie idiomu pieśni Mickiewiczowskiej oraz spopularyzowanie wybranych wierszy poety i sposób ich interpretacji muzycznej.

Pieśń do Wilii, która staje się obiektem zainteresowania w szóstym rozdziale analiz pierwszej części książki, skłania autorkę do głębszego przyjrzenia się kwestii muzycznych uwikłań twórczości Mickiewicza oraz sposobów, w jakie wzbogacił on tkankę epickiego Konrada Wallenroda o elementy muzyczne, i celów, dla których to czynił (s. 260-262). Trochę szkoda, że rozdział o kolejnym pieśniowym wyimku z tej powieści poetyckiej - Pieśni $z$ wieży - został przesunięty $\mathrm{w}$ książce dopiero na pozycję ósmą, zatem obie te części, w dużej mierze wobec siebie komplementarne, rozdzielone zostały przykładem sonetu Do Niemna (ten z kolei łączy się znaczeniowo z symboliką rzeki, która w Pieśni do Wilii zdradza wiele analogicznych cech). 
$\mathrm{Z}$ pewnością warto było podkreślić mocniej linie wiążące oba te walenrodyczne przypadki, aby uniknąć wrażenia (które odnieść można z lektury samego tylko rozdziału o pieśni Aldony), że problem muzyczności Konrada został nadmiernie zmarginalizowany.

W części poświęconej opracowaniom ballad kolejno przedstawiono omówienia Trzech Budrysów, Świtezianki, Czatów, Powrotu taty, Rybki i Pani Twardowskiej. Po części z uwagi na format tych kompozycji, które wielokrotnie przekraczają rozmiary pieśni lirycznych, a po części ze względu na podkreślane już pierwszoplanowe znaczenie Moniuszki i jego dorobku autorka zdecydowała się na wyraźniejsze, niż to było w omówieniu umuzycznień tekstów lirycznych, przesunięcie punktu ciężkości właśnie ku dziełom autora Halki. Doprowadza to, co prawda, do pewnej dysproporcji - fragmenty poświęcone balladom Moniuszki rozwijają się w samodzielne, kilkunastostronicowe opracowania, które prezentują pełne i rozbudowane analizy $\mathrm{i}$ interpretacje owych dzieł - niemniej jednak takie postępowanie wydaje się w pełni uzasadnione zarówno znaczeniem tych utworów, jak i ich walorami artystycznymi, udowadnianymi zresztą w toku analiz przez autorkę. Ponadto w tej części książki krystalizuje się wyraźna para porównawcza - Moniuszko i Carl Loewe, niemiecki kompozytor, który opracował wybrane ballady Mickiewicza w tłumaczeniach Carla von Blankenseego. Ten materiał pozwala uwypuklić odmienne u obu kompozytorów pojmowanie istoty ballady, a także różnice w interpretacji poszczególnych tekstów, niekiedy wszak wynikające z odmienności znaczeń tłumaczenia. Ze względu na tę ostatnią kwestię wyróżniają się bardzo ciekawe uwagi poświęcone tłumaczeniu $C z a-$ tów (s. 515 i n.), choć w interpretacji środkowej części ballady można byłoby zauważyć jeszcze kilka, poza wskazanymi, przesunięć semantycznych, które rysują postać młodzieńca w niemieckiej wersji tekstu jako bardziej wystylizowaną w duchu sentymentalnym i pozbawioną tak wyraźnego komponentu humorystycznego czy wręcz parodystycznego przerysowania, które cechuje go w oryginale Mickiewiczowskim i które mistrzowsko wykorzystał w swojej balladzie Moniuszko.

Podobnie jak we wcześniejszych rozdziałach także tu Sułek rozbudowuje ciekawe konteksty kulturowe, które - nawet jeśli przywołane wyłącznie w przypisach - poszerzają znacznie horyzonty badanego zjawiska, pozwalając czytelnikowi zobaczyć jego niespodziewane niekiedy ciągi dalsze i związki. Dotyczy to na przykład zacytowanych na s. 436-437 pieśni żołnierskich, parafrazujących balladę Trzech Budrysów. Z kolei rozdział o Świteziance stanowi właściwie samodzielną całość, minimonografię tej ballady. Do samego odczytania tekstu literackiego (s. 438-442) można byłoby zgłosić pewne zastrzeżenia autorka jak gdyby skapitulowała przed ogromem możliwości interpretacyjnych tej ballady i rozmaitości głosów wśród dotychczasowych komentatorów; niemniej jednak główną wartością są zgromadzone w kolejnych partiach rozdziału analizy kompozycji muzycznych: ballad Marii Szymanowskiej, Carla 
Loewego, Julii Brzozowskiej-Niewiarowskiej ${ }^{14}$, Stanisława Moniuszki, Nikołaja Rimskiego-Korsakowa, Adama Grossa, Apolinarego Szeluty oraz Marka Sarta i Zbigniewa Ciechana. W badaniach nad tą balladą, które wszak były już podejmowane, nie przeanalizowano jeszcze nigdy tak obszernego materiału.

Dominującym tropem, który podejmuje Sułek w swoich odczytaniach ballad, jest problematyka technik i motywów ilustracyjnych, wykorzystywanych przez kompozytorów w różny sposób do budowania własnej interpretacji tekstu. Autorka słusznie zwraca uwagę na istnienie „dwóch koncepcji twórczych - drobiazgowo odtwarzającej opisany przez poetę świat oraz kreującej, niejako nadpisującej składniki rzeczywistości jedynie przez poetę zasygnalizowane" (s. 524). Balansowanie między tymi możliwościami szczególnie mocno uwidacznia się właśnie w wypadku ballad, które z racji swojej narracyjno-dramatycznej specyfiki gatunkowej wydają się predestynowane do traktowania w ilustracyjno-odtwórczy sposób. Tymczasem spore różnice interpretacyjne, jakie zauważyć można choćby między wersjami umuzycznień Czatów Loewego i Moniuszki (w wypadku tym, podobnie jak w Trzech Budrysach, to polski twórca jest spadkobiercą i naśladowcą niemieckiego), świadczą o kompozytorskiej otwartości na niedopowiedzenia, nastrojowość i sensy wyłącznie sugerowane liryczną warstwą ballad literackich.

Książkę o muzycznych opracowaniach wierszy i ballad Mickiewicza wieńczy krótkie podsumowanie, w którym autorka syntetyzuje uzyskane rezultaty, podkreślając najistotniejsze osiągnięcia swoich analiz i interpretacji. Jedną z ważnych refleksji jest na przykład to, że pomimo, wydawałoby się, ogromnej tradycji badawczej tematu (wyliczenia pieśni do słów Mickiewicza powstawały wszak już w XIX wieku) dopiero teraz uzyskujemy względnie kompletny i zweryfikowany obraz tej spuścizny. Sułek nie tylko bowiem odnajduje nieznane uprzednio opracowania, wymienia te, których istnienie jest poświadczone - nawet jeśli nie stały się one przedmiotem omówienia, ale również obala mity na temat powstania pewnych pieśni, powtarzane do tej pory bezkrytycznie przez pokolenia badaczy (s. 652). Choć to Moniuszko, twórca najlepiej w Polsce zbadany spośród wszystkich bohaterów tej książki, znajduje się w centrum zainteresowania, publikacja otwiera przed czytelnikiem skarbiec całkowicie nieznanych kompozytorów (takich jak Zygmunt Biliński, Lucjan Laprus czy Lech Makowiecki), pozwalając spojrzeć na poezję Mickiewicza również ich oczami. Z kolei kompozytorzy skądinąd znani (jak Ignacy Jan Paderewski, Władysław Żeleński, Piotr Czajkowski, Cezar Cui) ujęci zostali

${ }^{14}$ Podkreślić trzeba, że autorka notuje nazwiska kompozytorki w kolejności odmiennej od tradycyjnej, choć zgodnej z porządkiem obyczaju (z domu Brzozowska, kompozytorka po mężu nosiła nazwisko Niewiarowska). Utrwalona w badaniach wersja nazwiska brzmi jednak Niewiarowska-Brzozowska. Tak na przykład funkcjonuje ta postać chociażby w katalogach polskich bibliotek, jak również w najpoważniejszym słowniku muzycznym Grove $\mathrm{Mu}$ sic Online - w poświęconym jej haśle autorstwa Zofii Chechlińskiej (https://doi.org/10.1093/ gmo/9781561592630.article.2021167, dostęp: 2.07.2018). 
w porównawczych seriach, co pozwoliło zobaczyć ich twórczość z nieco innej niż zwykle perspektywy. Wreszcie zestawienie obok siebie kompozycji wybitnych oraz - czego w swoim postępowaniu analitycznym dowodzi autorka - miernych, opracowujących te same teksty, daje czytelnikowi wgląd w nie tak oczywiste zasady rządzące relacją słowa i dźwięku w utworach wokalnych. Jak konstatuje Sułek: „,[u]twory muzyczne odznaczające się nabożnym wręcz poszanowaniem literackiego słowa częstokroć nie prezentowały należytego poziomu artystycznego" (s. 653).

Biorąc pod uwagę kulturę milczenia, w jakiej współcześnie egzystujemy pomimo wszechogarniającego chaosu dźwięków, towarzyszących nam każdego dnia - książka ta, przypominająca o wadze, jaką niegdyś posiadało słowo śpiewane, powszechnie dostępne, kształtujące horyzonty literackie odbiorców, ich nawyki czytelnicze, upodobania poetyckie, a nawet sposoby interpretacji tekstów, stanowi publikację niebywale istotną, która wejdzie na stałe do kanonu lektur poświęconych zagadnieniom liryki wokalnej w jej związku ze słowem. Widzieć w niej można jednak również wskazówkę do podjęcia w szerszym zakresie badań o specyficznej optyce, których potrzebę coraz mocniej odczuwa się w związku z bujnym rozkwitem dziedziny. Mam tu na myśli podejście syntetyzujące, całościowe, proponujące własne typologie i uporządkowania, ale zarazem zbierające wcześniejsze głosy poświęcone danemu zagadnieniu. Nawet jeśli w badaniach nad muzycznym Mickiewiczem książka Małgorzaty Sułek nie zamyka całego rozdziału (pozostają wszak wciąż nieopracowane przez nią inne Mickiewiczowskie teksty), to dowodzi potrzeby podsumowania etapu, zaproponowania ujęcia systematyzującego, które - nie krępując swobody przyszłych kontynuatorów - będą stanowić dla nich solidną podstawę.

\section{Bibliografia}

Barańczak A., Stowo w piosence. Poetyka polskiej piosenki estradowej, Wrocław 1983. Gamrat M., Między stowem a dźwiękiem. Pieśni na gtos i fortepian Franza Liszta, Warszawa 2016.

Hejmej A., Muzyczność dzieta literackiego, Wrocław 2001.

Hejmej A., Muzyka w literaturze. Perspektywy komparatystyki interdyscyplinarnej, Kraków 2008.

Libretto i przektad, red. E. Nowicka, A. Borkowska-Rychlewska, Poznań 2015.

Maleszyńska J., Apologia piosenki. Studia z historii gatunku, Poznań 2013.

Miraże identyfikacji. Libretto w operze XX i XXI wieku, red. A. Borkowska-Rychlewska, E. Nowicka, Poznań 2015.

Muzyka w literaturze. Antologia polskich studiów powojennych, red. A. Hejmej, Kraków 2002. 
„Natchnienia poety i muzyka żenić się z soba powinny”. Studia i szkice o libretcie, red. E. Nowicka, A. Borkowska-Rychlewska, Poznań 2013.

Od literatury do opery $i$ z powrotem. Studia nad estetyka teatru operowego, red. R.D. Golianek, P. Urbański, Toruń 2010.

Opera w kulturze, red. M. Sokalska, Kraków 2016.

Opera wobec historii, red. R.D. Golianek, P. Urbański, Toruń 2012.

Operowy kontrapunkt. Libretto w Europie Środkowej $i$ Wschodniej, red. B. Judkowiak, K. Lisiecka, Poznań 2014.

Seweryn A., Poezja „nutami niesiona”. O muzycznej recepcji twórczości Juliusza Stowackiego, Warszawa 2008.

Sułek M., Mickiewiczowskie „Pieśni mitosne” Franciszka Godebskiego [w:] Almanach muzykologii krakowskiej: 1911-2011, red. M. Woźna-Stankiewicz, Z. Dobrzańska-Fabiańska, A. Sitarz, Kraków 2016.

Sułek M., Pieśni masowe o Nowej Hucie, „Zeszyty Naukowe Towarzystwa Doktorantów UJ" 2010, z. 1.

Sułek M., Pieśni masowe Witolda Lutostawskiego w kontekście doktryny realizmu socjalistycznego, Kraków 2010.

Sułek M., Stanistaw Moniuszko i inni kompozytorzy wobec poezji Adama Mickiewicza. Studium komparatystyczne, Kraków 2016.

Sułek M., „Widma” Moniuszki wobec „Dziadów” Mickiewicza [w:] Teatr muzyczny Stanistawa Moniuszki, red. M. Dziadek, E. Nowicka, Poznań 2014.

Teatr muzyczny Verdiego i Wagnera. Konteksty literatury i kultury, red. R.D. Golianek, H. Winiszewska, Poznań 2015.

Traczyk M., Poezja w piosence. Od Tuwima do Świetlickiego, Poznań 2009. 